\title{
PROCES INTEGRACJ PRZEDSIĘBIORSTW TRADYCYJNYCH I FIRM INTERNETOWYCH W KONTEKŚCIE DZIAŁAŃ OFFSHORINGOWYCH I OUTSOURCINGOWYCH W POLSCE I NA ŚWIECIE
}

\begin{abstract}
WSTĘP
Offshoring i outsourcing, jako charakterystyczne kierunki integracji i współpracy polskich i zagranicznych przedsiębiorstw w latach dziewięćdziesiątych minionego wieku, współcześnie uchodzą za dwie z dziesięciu sił spłaszczających świat ${ }^{1}$ i permanentnie wykazują trend wzrostowy. Liczba przedsiębiorstw, które korzystają $\mathrm{z}$ analizowanych form współpracy, jak również udział firm, dla których te formy integracji stają się jednym $\mathrm{z}$ głównych elementów modelu biznesowego, wzrasta o około 20-30\% rocznie. Czynnikiem przemawiającym za korzystaniem z usług firm zewnętrznych o zasięgu krajowym i/lub zagranicznym jest głównie potrzeba koncentracji na priorytetowych celach i zadaniach, podczas gdy głównym aspektem przyjmowania roli usługodawcy w zakresie offshoringu lub outsourcingu są korzyści finansowe.

Analizowane formy integracji i współpracy zyskały swoich zwolenników głównie w Stanach Zjednoczonych, Chinach i Japonii. Także wiele znanych firm europejskich o zasięgu globalnym wykorzystuje offshoring i/lub outsourcing w swojej działalności biznesowej, ograniczając w ten sposób koszty działalności i poprawiając elastyczność działania między innymi: korporacji międzynarodowych, przedsiębiorstw, firm oraz innych podmiotów życia gospodarczego. Nie-
\end{abstract}


mniej jednak poza licznymi korzyściami analizowane formy integracji obarczone są także wieloma wadami.

\section{OFFSHORING I OUTSOURCING JAKO DWIE Z DZIESIĘCIU SIŁ PŁASKIEGO ŚWIATA}

Pod pojęciem „płaski świat” należy rozumieć alegorię wielu zdarzeń, jakie pojawiają się i przebiegają w różnych wymiarach otoczenia ludzi i organizacji. O płaskim świecie mówi się także wtedy, gdy pewne procesy i zjawiska, które niegdyś wydawały się ludziom tak odległe i niemożliwe, głównie przez występujące bariery: czasu, geograficzne i inne, współcześnie nie odgrywają żadnej roli, bądź ich znaczenie jest niewielkie. Powszechne wykorzystanie Internetu i innych środków komunikacji masowej sprawiło, że pozytywne i negatywne konsekwencje płaskiego świata dotyczą zarówno tych państw, firm, podmiotów i jednostek, które poddały się jego woli i zaangażowały w jego kreację, jak również społeczeństw, które nie są jeszcze gotowe otworzyć się na tę szeroko rozumianą integrację i współpracę.

Płaski świat bierze swoje korzenie w wydarzeniach o charakterze historycznym, które przybierają postać wskazówek, zakazów lub praw. Każde wydarzenie ma charakter siły, która wywołuje określone zmiany. Offshoring i outsourcing, jako dwie z dziesięciu sił, plasują się pośrodku tej klasyfikacji i mają swoje przełożenie na powstanie i funkcjonowanie innych. Do pozostałych ośmiu sił spłaszczających świat należą:

1) upadek muru berlińskiego;

2) rozwój sieci, World Wide Web (WWW) i przeglądarek internetowych, wejście na giełdę przeglądarki Netscape, dającej początek nowej kulturze aktywności w sieci;

3) powstanie i integracja oprogramowania umożliwiającego zarządzanie przepływem pracy między firmami i kontynentami $\left(\mathrm{SMTP}^{2}, \mathrm{HTML}^{3}\right.$ itp.);

4) uploading, tj. publikowanie $\mathrm{w}$ Internecie własnych przekazów: plików, zdjęć oraz innych materiałów i upowszechnianie ich zawartości na skalę globalną (ruch open source: Apache ${ }^{4}$, GNU/Linux; serwisy społeczno-

2 SMTP, czyli Simple Mail Transfer Protocol to protokól pozwalający wymieniać przesyłki mailowe między różnymi systemami komputerowymi.

3 HTML to język Internetu i sieci WWW pozwalający, by wszystkie napisane w nim dokumenty mogły być przesyłane przez sieć i odczytywane na dowolnym komputerze.

4 Apache to darmowy program typu open source, czyli tworzony przez społeczności, obsługujący ponad dwie trzecie stron internetowych na świecie. 
ściowe: Digg, MySpace, Facebook, Nasza - Klasa, Wikipedia, chat roomy, bloging itp.);

5) supply-chaining, czyli wykorzystanie łańcucha dostaw między dostawcami, sprzedawcami i klientami w celach tworzenia wartości dodanej (Wal-Mart);

6) insourcing, polegający na synchronizacji globalnego łańcucha dostaw dla różnych firm, zarówno dużych, jak i małych (UPS 5 , FedEx);

7) in-forming, polegający na możliwości zbudowania osobistego łańcucha dostaw informacji, wiedzy i rozrywki oraz stanowiący rodzaj współpracy z samym sobą (Google, Yahoo!, MSN Serach; urządzenia typu: TiVo, iPod i inne);

8) sterydy, tj. niektóre nowe technologie, przyczyniające się do wzmocnienia innych sił spłaszczających świat, na przykład: wydajność systemu komputerowego, komunikacja i wymiana plików on-line, telefonia internetowa, wideokonferencje, rozwój grafiki komputerowej oraz technologie i urządzenia służące do komunikacji bezprzewodowej.

Czynnikami wpływającymi na ewolucję płaskiego świata są głównie globalizacja i innowacje angażujące przedsiębiorstwa, firmy i ludzi w podejmowanie działań, które zapewniają komunikację z dowolnego miejsca na świecie. Także wszelka aktywność offshoringowa i outsourcingowa wymaga takiej komunikacji.

\section{UDZIAŁ OFFSHORINGU W PODEJMOWANIU WSPÓŁPRACY I INTEGRACJI RÓŻNYCH GRUP PRZEDSIĘBIORSTW W POLSCE I NA ŚWIECIE}

Globalizacja, rozwój technologii i „śmierć odległości” pociągnęły za sobą szereg istotnych zjawisk, między innymi w zakresie międzynarodowego podziału pracy i offshoringu ${ }^{8}$, stanowiącego ważny instrument kreowania biznesu. Zdaniem M. Krynickiego ${ }^{9}$ offshoring jest najbardziej jaskrawym przejawem globalnego zwrotu w działalności wytwórczej, prowadzącego do integracji przedsiębiorstw $\mathrm{z}$ różnych części świata i nowego międzynarodowego podziału pracy $\mathrm{w}$ sferze wytwarzania usług. $Z$ definicją offshoringu nierozerwalnie związane są aspek-

UPC - United Parcel Service to firma kurierska znana na całym świecie.

$6 \mathrm{TiVo}$ - urządzenie, za pośrednictwem którego każdy może stać się „redaktorem” programu telewizyjnego, tj. nagrać cyfrowo ulubione programy i oglądać je z pominięciem niechcianych reklam.

Por. I. Rybiński, Globalizacja w trzech odstonach, Wydawnictwo Difin, Warszawa 2007, s. 34.

Zwanego również captive offshoring.

M. Krynicki, Offshoring, http://www.bankier.pl/wiadomosc/Offshoring-1459477.html. 
ty wydzielenia i przeniesienia pewnych zadan, funkcji, usług lub etapów procesu wytwórczego firmy, które mogą być wykonywane na odległość, do innego kraju lub grupy krajów, celem zaś takiego działania jest próba obniżenia kosztów i/lub zwiększenia jakości bądź wydajności pracy.

Offshoring dotyczy głównie usług o charakterze information-intensive, czyli takich, które wymagają znacznego zaangażowania wiedzy i umiejętności realizatorów, jak również takich projektów, jak ${ }^{10}:$ call $_{\text {centres }}{ }^{11}$, shared services ${ }^{12}$ oraz Internet Technology (IT) ${ }^{13}$. Wszystkie one, dzięki wykorzystaniu Internetu i najnowszych rozwiązań łączności telefonicznej, dotyczą realizacji zadań dla tych firm i klientów, którzy mogą być oddaleni nawet o tysiące kilometrów. Innymi rodzajami offshoringu są ${ }^{14}$ : intra-firm offshoring, czyli ulokowanie własności działalności przedsiębiorstwa $\mathrm{w}$ innym państwie ${ }^{15}$, nearshoring, tj. wydzielanie usług do krajów sąsiadujących z krajami zlecającymi ${ }^{16}$, czy insourcing, czyli przekazanie procesów lub działań biznesowych jednostki, realizowanych w ramach działalności gospodarczej przez zewnętrznych usługodawców lub dostawców do wewnętrznej, wyodrębnionej i wyspecjalizowanej komórki organizacyjnej ${ }^{17}$.

Bendyk $^{18}$ pisze, że wzrastający udział teleinformatyki, wiedzy oraz offshoringu w tworzeniu wartości gospodarczej w płaskim świecie sprawia, że nie trzeba dziś emigrować, by czerpać korzyści z innowacji innych państw czy udziału w glo-

10 S. Czerniecki, Offshoring w Polsce, http://www.egospodarka.p1/9566,Offshoring-w-Polsce, $1,39,1 . h t m 1$.

11 Call center (in. centrum telefoniczne, centrum obsługi telefonicznej, biuro obsługi klienta BOK, centrum kontaktów z klientami) to całość elementów sprzętowych i programowych służących do obsługi masowych kontaktów z klientami przy użyciu telefonu jako medium. Główne zadania call center można podzielić na dwa zasadnicze obszary: obsługę połączeń przychodzących i obsługę połączeń wychodzących, których inicjatorem jest przedsiębiorstwo lub instytucja. Za: Call center, http://pl.wikipedia.org/wiki/Call_center.

12 Shared services odnosi się do świadczenia usług przez jedną część organizacji lub grupy, jeżeli taką usługę już wcześniej stwierdzono w więcej niż jednej części organizacji lub grupy. W ten sposób finansowanie i pozyskiwanie środków z usługi jest wspólne. Za: Shared service, http://en.wikipedia. org/wiki/Shared_services.

13 Organizacjami tego typu są również centra kompetencyjne, czyli rozbudowane organizacje, które w jednym miejscu skupiają wszystkich niezbędnych specjalistów z danej dziedziny, np. IT i finansów. Dzięki wszechstronności i kompleksowości świadczonych usług centra te są w stanie przejąć od wielkich korporacji wszelkie pozaprodukcyjne funkcje, mieszczące się w zakresie ich właściwości.

14 Por.J. Próchniak, Czy Polska traci na atrakcyjności?, „Pomorski Przegląd Gospodarczy” 2010, nr 2, s. 24-27.

15 Jest to kierunek charakterystyczny dla przedsiębiorstw, które nie podejmują decyzji o offshoringu ze względu na jakość i markę produktów.

16 Dla rynku europejskiego atrakcyjnymi lokalizacjami typu nearshore są: Polska, Czechy, Węgry, Bułgaria, Słowacja, natomiast dla Stanów Zjednoczonych - Meksyk i Kanada.

17 Insourcing, http://pl.wikipedia.org/wiki/Insourcing.

18 E. Bendyk, Opisać globalizacje, „Polityka” 2006, nr 50, s. 60. 
balnym rynku. Oznacza to, że informatyk z Indii lub Polski nie musi już wyjeżdżać do Stanów Zjednoczonych, żeby pracować dla amerykańskich klientów, albowiem tę odległość geograficzną można zniwelować dzięki Internetowi i środkom masowego przekazu. Stwierdzenie to obrazuje przykład: „Rybak z Bangladeszu uzbrojony w telefon komórkowy ma dostęp do aktualnej informacji o cenach i nie jest skazany na łaskę pośrednika-monopolisty, a informatyk z Indii nie musi jechać do Krzemowej Doliny, by świadczyć wysokiej jakości usługi”19.

Offshoring integruje przedsiębiorstwa $\mathrm{w}$ ramach jednego łańcucha produkcji. Współpraca ta sprawia, że firmy nie muszą już ze sobą konkurować. Sprzyja ona ponadto: redukcji kosztów, podniesieniu innowacyjności działań, a w efekcie wykorzystaniu globalnych zasobów kapitału intelektualnego, tworzeniu globalnej sieci dzielenia się wiedzą pomiędzy współpracującymi ze sobą jednostkami w różnych krajach, dywersyfikacji prowadzonej działalności i dopasowaniu świadczonych usług do potrzeb ich regionalnych odbiorców ${ }^{20}$.

Ekonomiczną podstawą offshoringu jest podział pracy związany z przewagą komparatywną. Oznacza to, że przedsiębiorstwo przenosi swoją produkcję do innych, tańszych krajów, gdyż pracownicy w tych krajach są w stanie wyprodukować lub przetworzyć te same dobra przy niższych kosztach pracy. Przekazując produkcję, która jest podstawową funkcją przedsiębiorstwa, do krajów tańszych, przedsiębiorstwo skupia się na procesach, które są na miejscu lub geograficznie bliżej, choć niekoniecznie są one wiodące dla organizacji ${ }^{21}$.

Wskazane zalety offshoringu nie przesłaniają jednak jego słabych stron, do których należą: odległość od macierzystej jednostki i jej wpływ na finanse i logistykę, bariery językowe, strefy czasowej i kulturowe, przepisy prawne, różnice kursu walutowego i inne.

\section{PRZYKŁADY OFFSHORINGU W DZIAŁALNOŚCI HANDLOWEJ I PRODUKCYJNEJ FIRM I PRZEDSIĘBIORSTW}

Integracja i współpraca zaczynają odgrywać coraz większą rolę w offshoringu, który dzięki tym aspektom może mieć swoje zastosowanie w odniesieniu do różnych sektorów i branż, czy usług, działalności i procesów produkcyjnych. Znanymi przykładami firm, które wykorzystują w swoich modelach biznesowych

\footnotetext{
19 Ibidem.

20 E. Carmel, P. Tjia, Offshoring Information Technology, Cambridge University Press, New
} York 2007, s. 10.

21 Outsourcing i offshoring, http://knol.google.com/k/outsourcing-i-offshoring\#. 
offshoring i jego formy pokrewne, są między innymi: Li\&Fung ${ }^{22}$, Adidas, Nike, Volkswagen czy Wal-Mart Stores, Inc. ${ }^{23}$ Przykładami firm zagranicznych, które działają w myśl offshoringu w Polsce, są ${ }^{24}$ :

- w zakresie centrów kontaktowych, których warunkiem funkcjonowania jest pozyskanie pracowników ze znajomością języków obcych: Stream International $^{25}$, KRUK ${ }^{26}$, Operator Telekomunikacyjny Dialog, Lukas Bank oraz Agencja handlowa ITP27;

- w zakresie Badań i Rozwoju (B+R), zatrudniając wykształconą siłę roboczą o specjalistycznych umiejętnościach: Pliva ${ }^{28}$, Avon, Delphi ${ }^{29}$;

- w sferze centrów usług wspólnych, które przejmują funkcje biznesowe od korporacji międzynarodowych i powstają w miejscach, gdzie niskie koszty pracy występują w połączeniu $\mathrm{z}$ wydajnością i jakością pracy: $\mathrm{KPMG}^{30}$, Philips i Thompson.

W przedsiębiorstwach tradycyjnych działania offshoringowe mogą dotyczyć głównie takich form aktywności, jak: produkcja, logistyka, księgowość, pomoc techniczna i archiwizacja danych. Przykładem przedsiębiorstwa tradycyjnego, wykorzystującego offshoring jest chińska firma Li\&Fung, największy na świecie outsourcer w branży odzieżowej z siedzibą w Hongkongu ${ }^{31}$. Opisywana firma nie jest właścicielem żadnej fabryki; nie posiada żadnej igły, jak również nie zatrudnia żadnych robotników fabrycznych ${ }^{32}$, niemniej jednak - jak podaje D.F. Spul-

22 Li\&Fung to przedsiębiorstwo założone w roku $1906 \mathrm{w}$ Chinach i specjalizujące się w pełnej organizacji zaopatrzenia na skalę globalną.

23 Wal-Mart Stores, Inc. to amerykańska sieć supermarketów założona w roku 1962 roku przez Sama Waltona.

24 D. Ciesielska, Wptyw offshoringu na rozwój przedsiębiorstwa w świetle koncepcji zarzqdzania wartościa firmy, http://www.e-finanse.com/artykuly/105.pdf.

25 Stream International należy do grupy światowych liderów w dziedzinie udzielania wsparcia technicznego producentom technologii elektronicznej, informatycznej oraz komunikacji. Specjalizuje się w dostarczaniu najwyższej jakości obsługi klienta oraz wsparcia technicznego użytkownikom sprzętu komputerowego, elektronicznego oraz telekomunikacyjnego.

${ }_{26}$ Grupa Kapitałowa KRUK jest liderem branży i kluczowym graczem zarówno w obszarze windykacji na zlecenie, jak również obrotu wierzytelnościami.

27 ITP działa w branży dystrybucji kosmetyków selektywnych.

28 Pliva to chorwackie przedsiębiorstwo farmaceutyczne z główną siedzibą w Zagrzebiu.

29 Delphi jest wiodącym światowym dostawcą rozwiązań elektronicznych i technologii systemowych dla sektora motoryzacyjnego. Koncern zainwestował w Polsce ponad 380 milionów USD, zarówno w produkcję, jak w badania i rozwój.

30 KPMG jest jedną z największych firm na świecie świadczących tzw. usługi profesjonalne (audyt, doradztwo podatkowe i doradztwo gospodarcze).

31 E. J. Malecki, B. Moriset, The digital economy: Business organization, production processes, and regional developments, Routledge, Taylor\&Francis Group, United States 2008, s. 78-81.

32 V. K. Fung, W. K. Fung, Y. Wind, Konkurowanie w ptaskim świecie. Budowanie przedsiębiorstw przystosowanych do ptaskiego świata, Wydawnictwa Akademickie i Profesjonalne, Warszawa 2008, s. 13. 
ber $^{33}$ - gromadzi zasoby siły roboczej w różnych krajach, liczące prawdopodobnie milion osób, które pracują dla jego dostawców. Firma zatrudnia także blisko cztery tysiące agentów, którzy podróżują między 37 różnymi krajami świata w celu znalezienia nowych dostawców i dokonują inspekcji w firmach obecnych dostawców celem znalezienie lepszych rozwiązań, obniżenia cen i wprowadzenia produktów wyższej jakości, mających służyć klientom i globalnym firmom współpracującym z Li\&Fung ${ }^{34}$.

Offshoring w działalności i firmach internetowych, typu: Amazon.com, eBay Inc., Carpetvista.com ${ }^{35}$ i wielu innych przybiera podobny charakter, co w firmach tradycyjnych. Model offshoringu w firmach internetowych najbardziej widoczny staje się wówczas, kiedy złoży się wizytę w centrali w East eBay w San Francisco. $\mathrm{W}$ porównaniu $\mathrm{z}$ bogatym bazarem na witrynie internetowej serwisu centrala firmy aukcyjnej jest zdumiewająco skromna. Pracownicy pracują w boksach, w tle zlokalizowano wielkie komputery, ważnym i obowiązkowym punktem na mapie centrali jest zaś bar kawowy, charakterystyczny dla Doliny Krzemowej. W centrali nie ma nawet śladu tego „czegoś”, czym ludzie handlują w serwisie aukcyjnym. Wszystko za sprawą przyjętego przez eBay Inc. modelu biznesowego, który jako jeden $z$ pierwszych w historii światowego handlu był modelem e-biznesowym, stworzonym na potrzeby firm i serwisów internetowych. To radykalnie odmienny pogląd w handlu detalicznym, w świetle którego piękno eBay i innych przedsięwzięć internetowych tego typu wynika $z$ dostrzeżenia przez właścicieli, że niczego nie muszą posiadać na własność: żadnych magazynów, fabryk i sklepów. Brak własności pozostawia klientom swobodę w budowaniu sklepów i stron oferowanych produktów odpowiednio do własnych potrzeb i umiejętności ${ }^{36}$.

Także inne firmy internetowe w swoich strukturach organizacyjnych wydzieliły szereg różnych usług, na przykład z zakresu informatyki, finansów czy księgowości oraz stworzyły własne specjalistyczne centra analityczne i procesowania, którymi już od kilku lat zajmują się niezależne podmioty zlokalizowane w różnych częściach świata.

\section{HISTORIA I ZASTOSOWANIE OUTSOURCINGU W PRZEDSIĘBIORSTWACH TRADYCYJNYCH}

Pierwsze samodzielne działania outsourcingowe przypadają na lata sześćdziesiąte XX wieku, podczas gdy sama koncepcja tej jednej z form współpracy i integracji

33 D. F. Spulber, Global competitive Strategy, Cambridge University Press, United States 2007, s. 84.

34 Ch. Hill, G. Jones, Strategic Management Theory: An Integrated Approach, South-Western Cengage Learning, United States 2008, s. 450.

35 Sklep internetowy oferujący szeroką gamę dywanów z całego świata.

36 W. K. Fung, V. K. Fung, Y. Wind, op. cit., s. 49-50. 
ukształtowana została już w latach dwudziestych XX wieku. Za pioniera outsourcingu uznaje się firmę Electronic Data Systems (EDS), należącą do Rossa Perota $^{37}$, która w roku 1963 jako pierwsza zaoferowała koncernowi Frito-Lay ${ }^{38}$ odpłatne usługi realizacji jego funkcji informatycznych. Oficjalnie pojęcie to zostało użyte w roku 1979 i dotyczyło kupowania niemieckich projektów przez brytyjski przemysł motoryzacyjny. Dynamiczny wzrost zainteresowania outsourcingiem przypada jednak na rok 2004 i związany jest między innymi z: istotną rolą w gospodarce światowej outsourcingu zagranicznego, czyli offshoringu, rewolucją informatyczną, umożliwiającą przeniesienie usług do krajów o niższych kosztach oraz globalizacją biznesu, tj. otwarciem gospodarek i deregulacją, połączoną z wymogiem dostarczania produktu najwyższej jakości po konkurencyjnej cenie ${ }^{39}$.

Stosowanie outsourcingu związane jest z koniecznością podjęcia ważnej decyzji: make or buy ${ }^{40}$. Myślą przewodnią outsourcingu jest koncentracja przedsiębiorstwa na własnych kompetencjach bazowych, podczas gdy wszystkie inne procesy, które nie stanowią specjalności przedsiębiorstwa, mogą być zlecane innym przedsiębiorstwom, czy firmom, dla których kompetencje te są kompetencjami bazowymi ${ }^{41}$. W tym miejscu rodzi się kwestia zagrożeń, jakie niesie z sobą model outsourcingu. Do najważniejszych należą:

- uzależnienie od firm zewnętrznych,

- możliwość utraty kontroli nad pewnymi funkcjami i cennymi informacjami,

37 Ross Perot (ur. 27 czerwca 1930 w Texarkana, Teksas) - przedsiębiorca amerykański, polityk, założyciel firm Electronic Data Systems i Perot Systems.

38 Frito-Lay to producent chrupek kukurydzianych, chipsów i innych przekąsek z Plano w stanie Teksas. Frito-Lay powstał z połączenia Frito i H.W. Lay\&Company w roku 1961. Cztery lata później Frito-Lay, Inc. połączył się z Pepsi-Colą, tworząc nową spółkę pod nazwą PepsiCo. Do produktów Frito-Lay należą między innymi: Fritos, Doritos, Cheetos, Ruffles, Lay's, Funyuns, Rold Gold, Smartfood, Tostitos, Munchos, Sun Chips, Walkers. Za: Frito-Lay, http://pl.wikipedia.org/ wiki/Frito-Lay.

39 T. Naspiński, Outsourcing ustug logistycznych w ramach zintegrowanego tańcucha dostaw, Studia Gdańskie, t. IV, Gdańska Wyższa Szkoła Humanistyczna, Gdańsk 2007, s. 147.

40 Pierwotnie outsourcing rozumiany był jako strategia zaopatrzenia, stosowana przez firmy produkcyjne, głównie motoryzacyjne, polegająca na rezygnacji z wytwarzania wszystkich prefabrykatów niezbędnych do produkcji, na rzecz pozyskiwania ich od innych producentów. Pod koniec wieku XX termin outsourcing zaczął być stosowany ogólnie do opisu strategii powierzania operacji wspierających główną działalność przedsiębiorstwa podmiotom zewnętrznym, specjalizującym się w zarządzaniu nimi. Obecnie outsourcing traktowany jest jako nowoczesna strategia zarządzania, polegająca na oddaniu innemu przedsiębiorstwu zadań niezwiązanych bezpośrednio z podstawową działalnością firmy, dzięki czemu może ona skupić swoje zasoby i środki finansowe na tych obszarach, które stanowią podstawę jej działań i w których osiąga przewagę konkurencyjną. Za: M. Amiti, W. ShangJin, Fear of Service Outsourcing. Is It Justified?, IMF Working Paper 2004, No. 6, s. 6-7.

${ }_{41}$ W zakresie usług specjalistycznych, które przedsiębiorstwa mogą kupować w ramach outsourcingu, znajdują się między innymi następujące obszary: usługi agencji reklamowych i public relations, badania rynków zbytu, usługi logistyczne, ochrona mienia, usługi w zakresie informatyki, szkolenia pracowników, podatki i księgowość. 
- obniżenie jakości produktów przez korzystanie z obcych źródeł zaopatrzenia lub niewłaściwe wykonanie usług,

- groźba utraty tożsamości, a w konsekwencji przewagi konkurencyjnej na skutek zatarcia granic między przedsiębiorstwem zlecającym a przedsiębiorstwami, które przyjmują zlecenie.

Outsourcing i jego inne formy wykorzystywane są najczęściej przez firmy z branż: logistycznej, hutniczej, informatycznej, hotelarskiej, bankowej, transportowej itp. Przykładami firm tradycyjnych wykorzystujących outsourcing mogą być:

- US Steel Kosice (w zakresie: obsługi strefy wolnocłowej, magazynowania surowców strategicznych, ochrony mienia, instalacji i obsługi urządzeń energetycznych, obsługi wózków widłowych, usług remontowych, sfery socjalnej, laboratoriów i kontroli jakości ${ }^{42}$ );

- Huty: Tadeusza Sendzimira, Łabędy i Batory (w zakresie usług IT, gospodarki zapasami, finansów i kosztów oraz systemów wspomagających zarządzanie);

- Wydawnictwa Szkolne i Pedagogiczne (w zakresie usług DTP, czyli komputerowego przygotowania druku'33);

- Urząd Miasta Katowice (w zakresie hostingu: serwisu WWW Urzędu Miasta, publikowania Biuletynów Informacji Publicznej Urzędu Miasta oraz Biuletynów Informacji Publicznej jednostek miejskich podległych Urzędowi Miasta Katowice, systemu publikowania ogłoszeń o zamówienia publiczne Urzędu i jednostek podległych Urzędowi Miasta Katowice; kolokacja serwera wraz z routerem zabezpieczającym ${ }^{44}$ ).

Outsourcingjakoformawspółpracy przedsiębiorstw tradycyjnychsłużykreacji tych procesów i zjawisk, które sprzyjają dalszemu rozwojowi życia gospodarczego, ekonomicznego, społecznego, jak również prowadzą do ograniczenia kosztów i/lub zwiększenia efektywności produkcji, tworząc nową wartość dodaną ${ }^{45}$. Ta integracja firm i przedsiębiorstw oraz łatwość komunikacji wspomaganej przez technologię służą także tworzeniu właściwych warunków i kreowaniu więzi między różnymi przedsiębiorstwami sytuowanymi w różnych obszarach geograficznych.

${ }^{42}$ US Steel Kosice to przedsiębiorstwo z branży hutniczej, działające w Europie Środkowo-Wschodniej.

43 K. Postrach, Problem decyzyjny - kupić czy wyprodukowwac? dzial?p_p_id=3 \&p_p_lifecycle=0\&p_p_state=maximized\&p_p_mode=view\&_3_struts_actio$\mathrm{n}=\% 2 \mathrm{Fsearch} \% 2 \mathrm{Fsearch}$.

44 J. Borys, Outsourcing informatyczny i kolokacja - wady i zalety pod katem wykorzystania w administracji, Urząd Miasta Katowice, Katowice 2005, s. 1-18.

$45 \mathrm{~S}$. Bloch, Ph. Whitley, Zarzadzanie w ptaskim świecie. Budowanie relacji w dobie globalizacji, Wydawnictwo Helion, Gliwice 2008, s. 30-42. 


\section{ZASTOSOWANIE OUTSOURCINGU W DZIAŁALNOŚCI FIRM I SERWISÓW ON-LINE NA PRZYKŁADZIE SERWISU AUKCYJNEGO ALLEGRO.PL}

Znanymi przykładami firm internetowych korzystających z outsourcingu są: QXL Poland, eBay Inc., Amazon, jak również liczne sklepy internetowe. Te ostatnie korzystają z outsourcingu kompleksowych rozwiązań e-commerce, których dostawcami w Polsce są między innymi: Soteshop, KQS.store, iStore.pl, osCommerce, Shoper.pl, Otwarte24.pl, Home.pl Business Shop i IAI-Shop.com ${ }^{46}$.

W obrębie analizowanych zagadnień interesujący wydaje się również przykład najpopularniejszego i największego w Polsce serwisu aukcyjnego Allegro.pl, należącego do firmy QXL Poland, będącej własnością afrykańskiego funduszu inwestycyjnego Naspers. Serwis Allegro.p1 ${ }^{47}$, w odróżnieniu od sklepów on-line i firm działających poza Internetem i korzystających $z$ usług outsourcingowych, nie posiada praw własności do żadnego ze sprzedawanych przedmiotów, głównym zaś źródłem przychodów QXL Poland są m.in. opłaty za wystawienie przedmiotów przez sprzedających ${ }^{48}$, prowizje $\mathrm{z}$ tytułu sprzedaży produktów i inne. W prowadzeniu serwisu Allegro.pl i innych serwisów zagranicznych, powiązanych z Allegro ${ }^{49}$, QXL Poland korzysta z outsourcingu wokół różnych zadań. Ta integracja $z$ innymi firmami i przedsiębiorstwami przebiega $w$ zakresie następujących czynności:

- przenoszenia i przechowywania zasobów informacyjnych;

- dostarczania infrastruktury sprzętowej;

- obsługi płatności internetowych;

- świadczenia usług w marketingu wyszukiwarek internetowych;

- skutecznych rozwiązań z zakresu marketingu interaktywnego i doświadczeń;

- przygotowania i przeprowadzenia kampanii reklamowych w mediach tradycyjnych; Internecie oraz telefonach komórkowych;

- organizacji, planowania, monitorowania i raportowania emisji banerów reklamowych na stronach internetowych;

- świadczenia usługi stałego dostępu do Internetu; s. $75-80$.

46 A. Mężyński, Outsourcing w przedsiębiorstwach branży internetowej, „e-Mentor” 2010, nr 5,

47 Jak również inne krajowe i zagraniczne serwisy aukcyjne, na przykład: Świstak.pl, Aukcjusz. pl, AukcjeFM.pl, Kiermasz.pl, serwisy grup eBay.com i eBid.com, DelCampe.

48 Zarówno indywidualnym sprzedającym, jak również sklepom i innym firmom, które sprzedają swoje towary lub usługi na Allegro.pl.

49 Chodzi o serwisy aukcyjne w krajach Europy Środkowo-Wschodniej, tj. w/na: Białorusi, Bułgarii, Czechach, Kazachstanie, Rosji, Rumunii, Serbii, Słowacji, Ukrainie i Węgrzech, których właścicielem jest QXL Poland. 
- organizacji systemu bezpieczeństwa transakcji on-line dokonywanych w serwisie;

- organizacji i przygotowywania ogólnopolskich eventów.

QXL Poland oraz inne firmy internetowe wykorzystują outsourcing dla zwiększenia efektywności prowadzonej działalności, jak również z takich względów, jak:

- koncentracja na działalności decydującej o pozycji konkurencyjnej i perspektywach przedsiębiorstwa;

- możliwość zwiększenia zakresu swobody w doborze partnerów współpracujących, uzyskując dostęp do know-how niemożliwego do osiągnięcia własnymi siłami;

- zwiększenie przychodów, redukcja kosztów oraz poprawa wyników ekonomicznych;

- ograniczenie ryzyka ekonomicznego prowadzonej działalności;

- redukcja lub uproszczenie struktury i procedur organizacyjnych;

- obiektywizacja wyników ekonomicznych;

- upowszechnienie myślenia i działania ekonomicznego;

- rozwój przedsiębiorczości.

Działania outsourcingowe prowadzone na zlecenie serwisu Allegro.pl i innych firm internetowych przyczyniają się do tego, że konkurujące dotąd ze sobą przedsiębiorstwa podejmują wspólpracę, dostosowując profil działalności do aktywności innych firm. Outsourcing w zakresie działalności internetowej to model współpracy charakterystyczny dla Globalizacji 3.0. Ten dynamiczny rozwój usług outsourcingowych w Internecie najbardziej zauważalny jest w przypadku tych serwisów, które stanowią platformę dla różnych ofert handlowych, na przykład: serwisów aukcyjnych i ogłoszeniowych, jak również serwisów zajmujących się udostępnianiem oprogramowania dla sklepów on-line z różnych branż.

\section{ZAKOŃCZENIE}

Procesy offshoringowe i outsourcingowe w zakresie produkcji i usług należą do często występujących form współpracy między korporacjami międzynarodowymi i innymi firmami, mającymi doprowadzić do uzyskania korzyści finansowych. Terminy te są często ze sobą mylone i używane wymiennie, co jest poważnym błędem, albowiem outsourcing to przesunięcie zamówień, produkcji lub usług do innej firmy, podczas gdy offshoring to także proces przesunięcia, ale poza granice kraju.

Z chwilą wejścia w XXI wiek rozpoczęła się trzecia fala offshoringu i outsourcingu, której cechami charakterystycznymi stały się bardziej skomplikowa- 
ne procesy biznesowe, oparte na wiedzy i dotyczące takich dziedzin, jak: badania i rozwój, medycyna, prawo, jak również usług specjalistycznych o wysokim stopniu skomplikowania, dostarczających klientom firm i przedsiębiorstw wysokiej wartości dodanej. Ta trzecia fala związana jest także, koniecznością poszukiwania przez niektóre przedsiębiorstwa czy firmy takich zasobów siły roboczej, która posiada zarówno przydatne umiejętności, jak również potrafi łączyć je w jedną specjalizację.

Polska, jak również inne kraje Europy Środkowej i Wschodniej, stała się jednym $z$ atrakcyjnych miejsc na mapie świata, do których swoją działalność decydują się przenosić międzynarodowe korporacje, uważając te regiony za atrakcyjne, pomimo że koszty pracy są tu wyższe w porównaniu na przykład z krajami azjatyckimi. Za atrakcyjnością naszego kraju i krajów wschodnio- i środkowoeuropejskich przemawiają głównie: wysoki poziom kształcenia i systemu edukacji, bliskość kulturowa, zbliżone modele biznesowe i e-biznesowe firm oraz przedsiębiorstw, przyjazny klimat dla inwestycji zagranicznych, dobra infrastruktura oraz niższe koszty pracy w porównaniu z krajami Europy Zachodniej i Stanów Zjednoczonych.

Ostatnie lata sprawiły, że firmy i przedsiębiorstwa tradycyjne i internetowe, na przykład: Allegro.pl, eBay Inc., Amazon, Microsoft, General Electric, Intel i American Express, postawiły na szybki rozwój, zakładając, że ich sukces i wysokie wyniki zależą również od umiejętnego zlecania części swoich procesów i usług konkurencyjnym firmom rodzimym i zagranicznym. Dla polskich i zagranicznych przedsiębiorstw wejście w obszar zmian stało się parametrem wskazującym na jego konkurencyjność, natomiast ciągły proces dostosowywania się do przeobrażeń, jakie nieustannie zachodzą w światowym handlu, jest wyznacznikiem tego, że przedsiębiorstwa zrozumiały: w czym przejawia się współpraca, za pomocą jakich mechanizmów i narzędzi powinny funkcjonować oraz jak ważne są dzisiaj outsourcing, offshoring i integracja w zakresie różnych działań.

\section{BIBLIOGRAFIA}

Amiti M., Shang-Jin W., Fear of Service Outsourcing. Is It Justified?, IMF Working Paper 2004, No. 6-7.

Bendyk E., Nowa Gospodarka. Kooperacja zamiast korporacji, „Polityka” 2006, nr 25.

Bendyk E., Opisać globalizację, „Polityka” 2006, nr 50.

Bendyk E., Wiele wymiarów globalizacji, http://www. liderzy.p1/img/312bf496.pdf.

Bloch S., Whitley Ph., Zarzadzanie w ptaskim świecie. Budowanie relacji w dobie globalizacji, Wydawnictwo Helion, Gliwice 2008.

Błoński M., Offshoring - bližej, coraz bliżej, http://www.outsourcing.com.pl/1038, offshoring_8211_blisko_coraz_blizej.html. 
Borys J., Outsourcing informatyczny i kolokacja - wady i zalety pod katem wykorzystania w administracji, Urząd Miasta Katowice, Katowice 2005.

Call center, http://pl.wikipedia.org/wiki/Call_center.

Carmel E., Tjia P., Offshoring Information Technology, Cambridge University Press, New York 2007.

Chan Kim W., Mauborgne R., Strategia btękitnego oceanu, „Harvard Business Rewiev Polska” 2008, nr 29-30.

Ciesielska D., Wptyw offshoringu na rozwój przedsiębiorstwa w świetle koncepcji zarzq̨dzania wartościa firmy, http://www.e-finanse.com/artykuly/105.pdf.

Czerniecki S., Offshoring w Polsce, http://www.egospodarka.pl/9566,Offshoring-w-Polsce, 1,3 9,1.html.

Friedman Th. J., Świat jest ptaski. Krótka bistoria XXI wieku, Dom Wydawniczy Rebis, Poznań 2006.

Frito-Lay, http://pl.wikipedia.org/wiki/Frito-Lay.

Fung V. K., Fung W. K., Wind Y., Konkurowanie w ptaskim świecie. Budowanie przedsiębiorstw przystosowanych do ptaskiego świata, Wydawnictwa Akademickie i Profesjonalne, Warszawa 2008.

Hill Ch., Jones G., Strategic Management Theory: An Integrated Approach, South-Western Cengage Learning, United States 2008.

Hirzel M., Mil und obne Partner. Alternativen beim Outsourcing von Verwaltungsdienst, „JO Management" 1997, No. 3.

Insourcing, http://pl.wikipedia.org/wiki/Insourcing.

Koliński A., Przekazanie ustug logistycznych w outsourcing, http://mojafirma.infor.pl/biznes-finanse/porady/116569,Przekazanie-uslug-logistycznych-w-outsourcing.html.

Krynicki M., Offshoring, http://www.bankier.pl/wiadomosc/Offshoring-1459477.html.

Lisiecki M., Outsourcing i Offshoring, http://www.europeistyka.uj.edu.pl/upload/173_d3f 0_Outsourcing_i_offshoring_-_mgr_M._Lisicki.pdf.

Malecki E. J., Moriset B., The digital economy: Business organization, production processes, and regional developments, Routledge, Taylor\&Francis Group, United States 2008.

Mężyński A., Outsourcing w przedsiębiorstwach branży internetowej, „e-Mentor”2010, nr 5.

Mierau A., Strategic Importance of Knowledge Process Outsourcing, Technical University of Kaiserslautern, Kaiserslautern 2007.

Naspiński T., Outsourcing ustug logistycznych w ramach zintegrowanego tańcucha dostaw, Studia Gdańskie, t. IV, Gdańsk 2007.

Nobis A., Ztożoność globalizacji, czyli różne globalne historie, „Kultura, historia, globalizacja” 2009 , nr 5.

Nocuj T., Offshoring w Polsce - plusy $i$ minusy, http://wiadomosci.nf.pl/News/1292/Offshoring-w-Polsce-plusy-i-minusy/.

Nowe oblicza outsourcingu w hutnictwie, CII Group, Katowice 2004.

Outsourcing i offshoring, 2011, [on-line], http://knol.google.com/k/outsourcing-i-offshoring\#.

Pindelski M., Czego boi się Thomas Friedman, „e-Mentor” 2007, nr 2/19.

Poinas J. P., Outsourcing w Europie. Ważny trend zyskujacy na znaczeniu, http://www. adp. pl/Outsourcing_Europa.cfm. 
Postrach K., Problem decyzyjny - kupic czy wyprodukowace? http://www.zie.pg.gda.pl/wydzial?p_p_id=3\&p_p_lifecycle=0\&p_p_state $=$ maximized\&p_p_mode $=v i e w \& \_3$ _ struts_action $=\% 2 \mathrm{Fsearch} \% 2 \mathrm{Fsearch}$.

Próchniak J., Czy Polska traci na atrakcyjności?, „Pomorski Przegląd Gospodarczy” 2010, nr 2.

Raport:polski rynek outsourcingu wart 1 miliard ztotych, http://www.forbes.p1/artykuly/ sekcje/aktualnosci/raport--polski-rynek-outsourcingu-wart-1-miliard-zlotych, 4159,1.

Rybiński I., Globalizacja w trzech odstonach, Wydawnictwo Difin, Warszawa 2007.

Rynek outsourcingu w Polsce rozkwita, http://investmap.pl/wiadomosci/rynek-outsourcin gu-w-polsce-rozkwita, $9390 . \mathrm{html}$.

Shared service, http://en.wikipedia.org/wiki/Shared_services.

Spulber D. H., Global competitive Strategy, Cambridge University Press, United States 2007.

\section{THE PROCESS OF INTEGRATION OF TRADITIONAL COMPANIES AND INTERNET COMPANIES IN THE CONTEXT OF OFFSHORING AND OUTSOURCING ACTIVITIES IN POLAND, AND WORLDWIDE \\ SUMMARY}

The main point of the thesis is an analysis of modern ways of managing business activity in Poland and over the world, based on cooperation and mutual connections, omitting competition, as one of significant terms of market economy. The reference to considerations of the thesis are examples of well-known companies and enterprises operating in traditional ways, as well as using the Internet channel and functioning only on the Internet. The examples used in order to illustrate these targets are: QXL Poland and Allegro, eBay Inc., Li\&Fung, Wal-Mart and others. The main terms, characteristic for the discussed issue include: outsourcing and offshoring. 